Article

\title{
Diversity and Ecology of Marine Algicolous Arthrinium Species as a Source of Bioactive Natural Products
}

\author{
Young Mok Heo ${ }^{1}$, Kyeongwon Kim ${ }^{1}$, Seung Mok Ryu ${ }^{2}$, Sun Lul Kwon ${ }^{1}$, Min Young Park ${ }^{2}$, \\ Ji Eun Kang ${ }^{2}$, Joo-Hyun Hong ${ }^{1}$, Young Woon Lim ${ }^{3}$, Changmu Kim ${ }^{4}$, Beom Seok Kim ${ }^{2}$, \\ Dongho Lee ${ }^{2, *}$ and Jae-Jin Kim ${ }^{1, * \mathbb{D}}$ \\ 1 Division of Environmental Science \& Ecological Engineering, College of Life Sciences \& Biotechnology, \\ Korea University, Seoul 02841, Korea; hym011@korea.ac.kr (Y.M.H.); rudndjs@korea.ac.kr (K.K.); \\ sun-lul@korea.ac.kr (S.L.K.); dress8@korea.ac.kr (J.-H.H.) \\ 2 Division of Biotechnology, College of Life Sciences \& Biotechnology, Korea University, Seoul 02841, Korea; \\ mogijjang@korea.ac.kr (S.M.R.); min0@korea.ac.kr (M.Y.P.); heyyo9725@korea.ac.kr (J.E.K.); \\ biskim@korea.ac.kr (B.S.K.) \\ 3 School of Biological Sciences and Institute of Microbiology, Seoul National University, Seoul 08826, Korea; \\ ywlim@snu.ac.kr \\ 4 Microorganism Resources Division, National Institute of Biological Resources, Incheon 22689, Korea; \\ snubull@korea.kr \\ * $\quad$ Correspondence: dongholee@korea.ac.kr (D.L.); jae-jinkim@korea.ac.kr (J.-J.K.); Tel.: +82-2-3290-3017 (D.L.); \\ +82-2-3290-3049 (J.-J.K.); Fax: +82-2-953-0737 (D.L.); +82-2-3290-9753 (J.-J.K.)
}

Received: 8 November 2018; Accepted: 10 December 2018; Published: 14 December 2018

check for updates

\begin{abstract}
In our previous study, all Arthrinium isolates from Sargassum sp. showed high bioactivities, but studies on marine Arthrinium spp. are insufficient. In this study, a phylogenetic analysis of 28 Arthrinium isolates from seaweeds and egg masses of Arctoscopus japonicus was conducted using internal transcribed spacers, nuclear large subunit rDNA, $\beta$-tubulin, and translation elongation factor region sequences, and their bioactivities were investigated. They were analyzed as 15 species, and 11 of them were found to be new species. Most of the extracts exhibited radical-scavenging activity, and some showed antifungal activities, tyrosinase inhibition, and quorum sensing inhibition. It was implied that marine algicolous Arthrinium spp. support the regulation of reactive oxygen species in symbiotic algae and protect against pathogens and bacterial biofilm formation. The antioxidant from Arthrinium sp. 10 KUC21332 was separated by bioassay-guided isolation and identified to be gentisyl alcohol, and the antioxidant of Arthrinium saccharicola KUC21221 was identical. These results demonstrate that many unexploited Arthrinium species still exist in marine environments and that they are a great source of bioactive compounds.
\end{abstract}

Keywords: antioxidant; biological control; ecological role; gentisyl alcohol; multi-gene phylogeny; tyrosinase inhibition

\section{Introduction}

Among a number of marine fungi isolated from a brown alga Sargassum sp., Arthrinium spp. showed high levels of cellulolytic enzyme productivity, radical-scavenging, or antifungal activities [1]. To date, however, studies on marine Arthrinium spp. are insufficient in terms of reliable phylogenetic analysis, physiological activity, bioactive secondary metabolites, and ecology.

The genus Arthrinium Kunze (sexual morph Apiospora; Ellis 1971 [2], Apiosporaceae) was reported as an endophyte in plant and ecologically-diverse species occurring in various habitats in both 
terrestrial and marine environments [3,4]. The genus Arthrinium has numerous broad synonyms [5]. Cordella is a potential synonym for Arthrinium and distinguished primarily by the existence of setae. Pteroconium, with the uncertain status of its generic name, has been regarded as an individual genus separate from Arthrinium, although Apiospora is the sexual morph of both Pteroconium and Arthrinium [2,5,6]. Currently, 80 Arthrinium species are reported in Index Fungorum (2018), but most Arthrinium taxa do not have enough sequence data and lack a detailed description of their morphological characteristics. Recently, the genus Arthrinium was re-examined by phylogenetic analysis of 16 species, which suggested that it is necessary to use $\beta$-tubulin (TUB) and translation elongation factor (TEF) regions to resolve species complexes [4]. Recently, Wang et al. (2018) published eight new Arthrinium spp. using three combined loci and multi-gene phylogenetic analysis with high bootstrap supports [7].

Marine-derived fungi have been suggested as a novel source of bioactive secondary metabolites, which can be applied in the pharmaceutical and cosmetic industry [8]. This suggestion was due to cephalosporin C production by Acremonium chrysogenum being reported in 1961 as the first bioactive metabolite from marine fungi, but novel natural compounds from marine fungi were less explored in comparison with compounds from terrestrial fungi [9]. Marine natural compounds have provided sufficient interest to the pharmaceutical industry due to their unique chemical properties [10]. In particular, marine fungal endophytes have been recognized as potential producers for bio-based commercial products [11]. Marine Arthrinium spp. have been reported as an endo-symbiont of marine algae, especially brown algae. They have been discovered to produce natural compounds such as arthrinone, arthrichitin, terpestacin, (1R,2S,3aS,8aR)-3a,6-dimethyl-1-(propan-2-yl)-1,2,3,3a,4,7,8,8a-octahydroazulene-1, 2-diol (CAF-603), norlichexanthone, myrocins, libertellenones, spiroarthrinols, and griseofulvin derivatives [12-15]. However, a limited number of bioactive compounds were reported: arthpyrones F-I and apiosporamide (antibacterial) [16]; arthrinins A-D (antitumoral and antiproliferative) [13]; decarboxyhydroxycitrinone, myrocin A, libertellenone $\mathrm{C}$, and cytochalasin $\mathrm{E}$ (antiangiogenic); arthone $C$ and 2,3,4,6,8-pentahydroxy-1-methylxanthone (antioxidant) [17]; and cytochalasin $\mathrm{K}$ and 10-phenyl-[12]-cytochalasin $Z_{16}$ (cytotoxic) [18]. In this regard, it was suggested that marine Arthrinium spp. have great potential to produce various bioactive compounds that can be the ingredients of a wide range of bioagents, many of which have not been discovered yet. In this study, the biological activities of marine Arthrinium spp. extracts were investigated to evaluate the value of marine Arthrinium spp. as a source of bioactive compounds and to infer their ecological role in symbiotic relationships with marine algae.

The aims of this study were (1) to identify and phylogenetically analyze marine-derived Arthrinium spp., (2) to evaluate the pharmaceutical value of marine Arthrinium spp. as a source of bioactive compounds, (3) to evaluate the ecological role in symbiosis with brown algae, and (4) to isolate and structurally identify a bioactive compound from marine Arthrinium species.

\section{Results and Discussion}

\subsection{Identification and Multi-Gene Phylogeny}

A total of 28 marine-derived Arthrinium strains were isolated from an unknown seaweed, Sargassum sp., Agarum cribrosum, and egg masses of Arctoscopus japonicus (Table 1). For the phylogenetic analysis, we constructed a phylogenetic tree using combined datasets from internal transcribed spacers (ITS), partial nuclear large subunit rDNA (LSU), TUB, and TEF 1-alpha (EF-1 $\alpha$ ) region sequences containing 45 taxa and 680,559, 590, and 534 nucleotide characters, respectively (Figure 1). As the results of the MrModeltest with the Akaike information criterion (AIC), a general time reversible (GTR) + proportion of invariable sites (I) + gamma distribution (G) model was chosen for LSU and TUB, and the symmetrical model $(\mathrm{SYM})+\mathrm{I}+\mathrm{G}$ model and Hasegawa-Kishino-Yano (HKY) + I + G model were chosen for ITS and EF-1 $\alpha$, respectively. The form of the tree demonstrated that all the species were clustered with high posterior probabilities (95-100\%). As a result, the 28 Arthrinium strains were divided into 15 species, including 11 novel species candidates. All new species will be reported in the near future. 
Table 1. General information for the 28 marine-derived Arthrinium spp. and antioxidant activity of the fungal extracts.

\begin{tabular}{|c|c|c|c|c|c|c|c|c|}
\hline \multirow{2}{*}{ Fungal Identity } & \multirow{2}{*}{ Strain ID } & \multirow{2}{*}{ Isolation Source } & \multicolumn{4}{|c|}{ GenBank Accession Number } & \multicolumn{2}{|c|}{ Antioxidant Activity $\left(\mathrm{IC}_{50}, \mu \mathrm{g} / \mathrm{mL}\right.$} \\
\hline & & & ITS & LSU & TUB & EF-1 $\alpha$ & ABTS $^{a}$ & DPPH $^{b}$ \\
\hline \multirow[t]{4}{*}{ A. arundinis } & KUC21229 & Sargassum fulvellum & KT207747 & MH498470 & MH498512 & MH544684 & 40.55 & $>1000$ \\
\hline & KUC21261 & Sargassum fulvellum & KT207779 & MH498469 & MH498511 & MH544683 & 52.33 & $>1000$ \\
\hline & KUC21335 & Unknown seaweed & MH498552 & N.D. & MH498510 & N.D. & 64.89 & N.D. \\
\hline & KUC21337 & Beach sand & MH498551 & MH544659 & MH498509 & MH544682 & $>100$ & $>1000$ \\
\hline A. marii & KUC21338 & Unknown seaweed & MH498549 & MH498467 & MH498507 & MH544681 & 74.77 & N.D. \\
\hline A. sacchari & KUC21340 & Egg masses of Arctoscopus japonicus & MH498548 & MH498466 & MH498506 & MH544680 & 17.45 & 601.34 \\
\hline \multirow{4}{*}{ A. saccharicola } & KUC21221 & Sargassum fulvellum & KT207737 & KT207687 & KT207637 & MH544679 & 14.09 & 59.19 \\
\hline & KUC21341 & Egg masses of Arctoscopus japonicus & MH498547 & MH498465 & MH498505 & N.D. & $>100$ & N.D. \\
\hline & KUC21342 & Egg masses of Arctoscopus japonicus & MH498546 & MH498464 & MH498504 & N.D. & 58.27 & N.D. \\
\hline & KUC21343 & Egg masses of Arctoscopus japonicus & MH498545 & MH498463 & MH498503 & MH544678 & 38.81 & 744.32 \\
\hline \multirow[t]{5}{*}{ Arthrinium sp. 1} & KUC21228 & Sargassum fulvellum & KT207746 & KT207696 & KT207644 & MH544677 & 55.29 & N.D. \\
\hline & KUC21232 & Sargassum fulvellum & KT207750 & KT207700 & KT207648 & MH544676 & $>100$ & $>1000$ \\
\hline & KUC21282 & Sargassum fulvellum & MH498544 & MH498462 & MH498502 & MH544675 & 45.37 & $>1000$ \\
\hline & KUC21284 & Sargassum fulvellum & MF615228 & MF615215 & MF615233 & MH544674 & 100.04 & $>1000$ \\
\hline & KUC21334 & Egg masses of Arctoscopus japonicus & MH498543 & MH544661 & MH498501 & MH544673 & 50.89 & $>1000$ \\
\hline \multirow[t]{3}{*}{ Arthrinium sp. 2} & KUC21220 & Sargassum fulvellum & KT207736 & KT207786 & KT207636 & MH544672 & 23.23 & $>1000$ \\
\hline & KUC21279 & Sargassum fulvellum & MF615229 & MF615216 & MF615234 & MH544671 & 41.71 & $>1000$ \\
\hline & KUC21280 & Sargassum fulvellum & MH498542 & MH544660 & MH498500 & N.D. & 61.43 & $>1000$ \\
\hline Arthrinium sp. 3 & KUC21327 & Egg masses of Arctoscopus japonicus & MH498541 & MH498461 & MH498499 & MH544670 & 10.32 & $>1000$ \\
\hline Arthrinium sp. 4 & KUC21328 & Unknown seaweed & MH498538 & MH498458 & MH498496 & MH544669 & 19.22 & $>1000$ \\
\hline \multirow{2}{*}{ Arthrinium sp. 5} & KUC21288 & Unknown seaweed & MF615230 & MF615217 & MF615235 & MH544668 & 50.32 & $>1000$ \\
\hline & KUC21289 & Unknown seaweed & MF615226 & MF615213 & MF615231 & MH544668 & 61.63 & $>1000$ \\
\hline Arthrinium sp. 6 & KUC21321 & Unknown seaweed & MH498533 & MH498453 & MH498491 & N.D. & 46.98 & $>1000$ \\
\hline Arthrinium sp. 7 & KUC21329 & Egg masses of Arctoscopus japonicus & MH498531 & MH498451 & MH498489 & MH544666 & 39.05 & $>1000$ \\
\hline Arthrinium sp. 8 & KUC21330 & Egg masses of Arctoscopus japonicus & MH498530 & MH498450 & MH498488 & MH544665 & 72.56 & $>1000$ \\
\hline Arthrinium sp. 10 & KUC21332 & Egg masses of Arctoscopus japonicus & MH498524 & MH498444 & MH498482 & MH544664 & 14.87 & 73.22 \\
\hline Arthrinium sp. 11 & KUC21333 & Agarum cribrosum & MH498520 & MH498440 & MH498478 & MH544663 & 32.62 & $>1000$ \\
\hline Arthrinium sp. 12 & KUC21322 & Unknown seaweed & MH498515 & MH498435 & MH498473 & MH544662 & $>100$ & $>1000$ \\
\hline Ascorbic acid * & & & & & & & 13.70 & 6.80 \\
\hline
\end{tabular}

N.D. means no data or not detected. ${ }^{a}$ ABTS, $2.2^{\prime}$-azino-bis-3-ethylbenzothiazoline-6-sulfonic acid; ${ }^{b}$ DPPH, 2,2-diphenyl-1-picrylhydrazyl; ${ }^{*}$ positive control for antioxidant activity. 


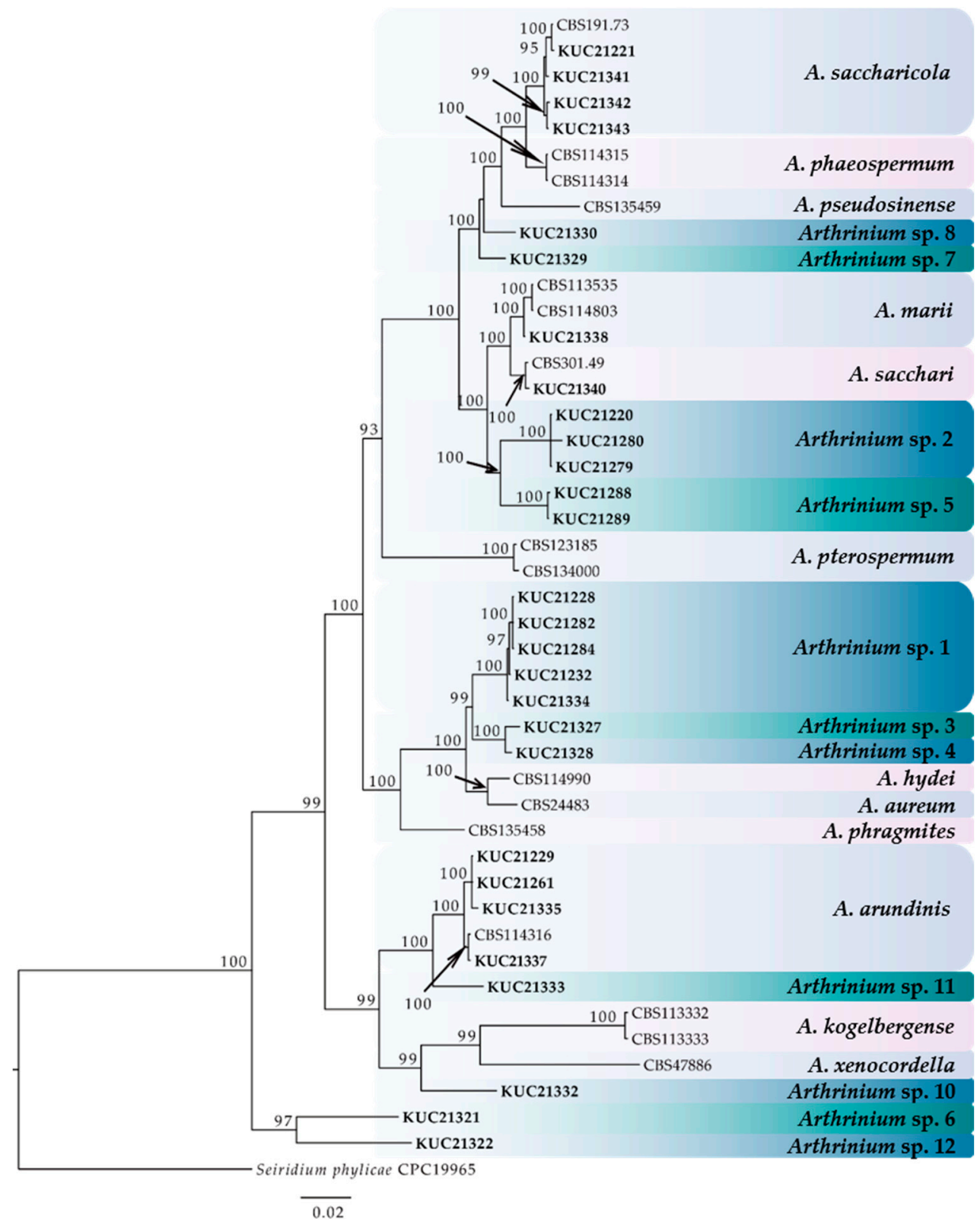

Figure 1. The phylogenetic tree of the Arthrinium species based on the combined ITS, LSU, TUB, and EF- $1 \alpha$ sequence alignment from Bayesian analysis using MrBayes v. 3.2.1. The dataset was created from 45 taxa and 2363 characters. The fungal cultures examined in this study are boldfaced. The number above the branch indicates the posterior probability values $\geq 70$. The scale bar indicates nucleotide substitutions per position.

\subsection{Marine Habitat of Arthrinium}

Most of the Arthrinium species isolated from each substrate were identified to be different (Table 1). Seven different Arthrinium species were isolated from the egg masses of $A$. japonicus. The two known species were Arthrinium saccharicola and $A$. sacchari, and the other five strains were considered novel Arthrinium candidates. Interestingly, A. saccharicola, A. arundinis, and Arthrinium sp. 1 were found in both Sargassum fulvellum and the egg masses of A. japonicus [19]. A. japonicus spawns the largest number of eggs on Sargassum fulvellum, one of the major endophytic hosts of Arthrinium spp. [20]. It was strongly speculated that the separation of the same Arthrinium species from both substrates was based on this fact. The conidia of the algicolous Arthrinium spp. can easily be transferred to the egg masses of $A$. japonicus. In another study, the fungal diversity of the $A$. japonicus egg masses were 
investigated, and eight Arthrinium species were founded: A. saccharicola, A. sacchari, A. phaeospermum, A. arundinis, and $A$. rasikravindri, as well as three unknown Arthrinium species [19]. According to Park et al. (2018), Arthrinium accounts for a small portion of the strains isolated from egg masses of A. japonicus. Nonetheless, the fact that there were many new species candidates suggests that various unexplored Arthrinium species are present in the marine environment.

A. saccharicola, known as a plant pathogenic fungus, has been isolated from living and dead culms of Phragmites australis and even from the air in the Netherlands and France and from seawater in mangrove habitats in Hong Kong [4,21]. This suggested that $A$. saccharicola has low host specificity. Additionally, A. arundinis, A. marii, and A. sacchari have been isolated from more than one substrate in another study [7]. A. arundinis has been isolated from the leaf of Hordeum vulgare and living leaves of Fagus sylvatica in Iran and Switzerland [4]. Additionally, in a recent study, 19 strains of A. arundinis were isolated from nine different hosts in China [7]. Taxonomical work on Arthrinium species isolated from marine ecosystems has been relatively lacking compared to work on those isolated from terrestrial ecosystems. Thus, more taxonomic and systematic analyses of marine-derived Arthrinium spp. are needed.

\subsection{Biological Activities of Marine Arthrinium spp.}

\subsubsection{Antioxidant Activity}

Since Arthrinium spp. showed high antioxidant activity, other marine-derived Arthrinium species were also expected to do so [1]. The results showed that almost every Arthrinium strain showed high radical-scavenging activity on the assay using 2.2'-azino-bis-3-ethylbenzothiazoline-6-sulfonic acid (ABTS) radicals as a substrate (Table 1). In particular, the crude extract of Arthrinium sp. 3 KUC21327 exhibited even higher ABTS radical-scavenging activity than ascorbic acid. Reactive oxygen species (ROS) are responsible for many kinds of diseases and aging because they damage biomolecules, such as DNA and protein, through oxidative chain reactions [22]. This suggests that the symbiotic relationship between Arthrinium spp. and their major host, seaweeds, may be based on the regulation of the ROS-defense system. Many seaweeds have been used as functional food and cosmetic ingredients because of their great antioxidant ability [23,24]. It was speculated that these algicolous fungi might contribute to the antioxidant ability of seaweeds.

Researchers have discovered many kinds of antioxidants, which can scavenge free-radicals generated from ROS, and filamentous fungi were one of the main natural sources of antioxidants. Filamentous fungi produce a wide range of secondary metabolites, and many polyphenolic compounds have been reported to exhibit high radical-scavenging abilities against ROS and free radicals [25]. In the case of marine Arthrinium spp., arthone $C$ and 2,3,4,6,8-pentahydroxy-1-methylxanthone were reported as antioxidants [17]. Our ABTS assay results imply that marine-derived Arthrinium spp. commonly produce certain kinds of antioxidant compounds. Among them, A. sacchari KUC21340, A. saccharicola KUC21221, A. saccharicola KUC21343, and Arthrinium sp. 10 KUC21332 exhibited high radical-scavenging activity against the 2,2-diphenyl-1-picrylhydrazyl (DPPH) radical. Because the reaction media of ABTS and DPPH assays differ (PBS buffer and $80 \% \mathrm{MeOH}$, respectively), the measured activity is affected by the solubility of potential antioxidant compounds for each solvent [26]. These four strains produce antioxidant compounds that are less hydrophilic than those of the other strains and remain active in $\mathrm{MeOH}$. In particular, the $\mathrm{IC}_{50}$ values of $A$. saccharicola KUC21221 and Arthrinium sp. 10 KUC21332 were significantly lower than those of the other species, implying that these species have high antioxidative capacities. The high radical-scavenging activity of $A$. saccharicola KUC21221 extract was already reported [1]. Among the two candidates, Arthrinium sp. 10 was selected in consideration of the novelty of this fungal species, its antioxidant compound was separated, and the chemical structure was identified. 


\subsubsection{Antifungal Activity}

In our previous study, all six Arthrinium sp. isolated from Sargassum sp., a brown alga, exhibited high antifungal activities against terrestrial plant pathogens [1]. As Arthrinium spp. are one of the key endophytes of seaweed, some Arthrinium species were expected to have symbiotic relationships in immune mechanisms by producing antibiotics against other marine microorganisms harmful to the algae. As a result, the extracts of three A. saccharicola (KUC21221, KUC21341, and KUC21343) and Arthrinium sp. 2 KUC21220 showed inhibitory effects against mycelial growth of the test fungus Asteromyces cruciatus, an alginate-degrading fungus (Table S2). Alginate is a major constituent of brown algae and plays an important role in brown algae by forming the structure of the algal biomass and physically protecting algae from pathogens [27]. Some marine fungi have been reported to be able to degrade alginate: Asteromyces cruciatus, Corollospora intermedia, Dendryphiella arenaria, and D. salina [28]. In particular, A. cruciatus is one of the major marine colonizers ubiquitous in the marine environment [29]. This fungus can be regarded as a potentially harmful microorganism to brown algae, as it can colonize the entire algal biomass and breakdown alginate enzymatically when the defense system of algae is weakened. Decomposition of the biomaterial leads to the collapse of the defense system.

In particular, the two A. saccharicola (KUC21341 and KUC21342) extracts had the highest antifungal activities as they could inhibit the growth of $A$. cruciatus at a concentration of $100 \mu \mathrm{g} / \mathrm{mL}$. Since they were identified as the same species, the antifungal secondary metabolites are highly likely to be identical. This result implied that the two Arthrinium species, especially A. saccharicola, may have a symbiotic relationship with brown algae that assists its defense system against other marine fungi. Furthermore, it was strongly speculated that their antifungal metabolites can affect other pathogenic fungi, considering that six marine-derived Arthrinium strains (A. arundinis KUC21229 and KUC21261, A. saccharicola KUC21221, Arthrinium sp. 1 KUC21228 and KUC21232, and Arthrinium sp. 2 KUC21220) showed antifungal activity against several terrestrial plant pathogenic fungi [1]. Considering that most antimicrobials have low specificity, it was thought that they might have evolved to synthesize antifungal compounds not only for themselves, but also for their symbiotic partner, marine algae. Plants are protected by cocktails of moderately-active compounds, such as essential oils, and synergy with antimicrobials lowers the minimum effective concentration of individual antimicrobial compound to prevent the emergence of resistant pathogens [30]. Similarly, it was suggested that the broad spectrum antifungal potential of these marine algicolous Arthrinium spp. may contribute to improving the fitness of the algal hosts by providing a broad spectrum of defense that does not trigger the emergence of resistant pathogens. It is necessary to study the interaction between antimicrobials of Arthrinium spp. and secondary metabolites of the algal hosts.

\subsubsection{Tyrosinase Inhibition Activity}

A total of eight Arthrinium extracts exhibited inhibitory activity against tyrosinase, and A. sacchari KUC21340, Arthrinium sp. 2 KUC21279, and Arthrinium sp. 7 KUC21329 were the best producers of tyrosinase inhibitors (Table S2). Tyrosinase catalyzes the oxidation of not only tyrosine, but also L-3,4-dihydroxyphenylalanine (L-DOPA), a reactive intermediate compound of melanin, to dopaquinone, which eventually converts it to pheomelanin [31]. Tyrosinase inhibitors suppress the formation of melanin in human skin and prevent the darkening of the skin tone, and researchers have discovered several inhibitors of fungal origin, such as protocatechualdehyde from Phellinus linteus, 6-n-pentyl- $\alpha$-pyrone from Myrothecium sp., and kojic acid, the most widely-studied tyrosinase inhibitor, from various fungi, especially Aspergillus oryzae [32-34]. These tyrosinase inhibitors have various mechanisms, and many antioxidant compounds have been reported to exhibit tyrosinase inhibition activity by suppressing melanin biosynthesis by scavenging reactive quinone products [31]. The extracts of A. sacchari KUC21340, Arthrinium sp. 2 KUC21279, and Arthrinium sp. 7 KUC21329 exhibited both tyrosinase inhibitory and radical-scavenging activity, and it can be interpreted that the tyrosinase inhibitors can be identical to their antioxidant compounds. This result indicates that 
the three Arthrinium species can produce tyrosinase inhibitors with antioxidant activity that regulates melanin biosynthesis by scavenging reactive quinone products.

\subsubsection{Quorum Sensing Inhibition Activity}

The extracts of Arthrinium sp. 1 KUC21228 and KUC21232 and Arthrinium sp. 6 KUC21321 inhibited the production of violacein by C. violaceum CV026 in the presence of $\mathrm{N}$-(3-oxo-hexanoyl)-L-homoserine lactone (3-oxo-C6-HSL), an $\mathrm{N}$-acyl homoserine lactone (AHL), which is one of the most widely-studied quorum sensing (QS) molecules (Figure 2). In particular, Arthrinium sp. 1 KUC21228 extract showed a high inhibitory activity even comparable to that of the positive control, which is a pure compound (Figure 2A). QS is responsible for the formation of bacterial biofilms and the expression of virulence genes, and bacterial biofilms have been reported to be approximately 1000-times more resistant to antibiotics than their planktonic counterparts [35]. Some fungi produce quorum-quenching compounds such as patulin and penicillic acid from Penicillium spp., which can suppress bacterial biofilm formation [36]. All four Arthrinium strains that showed QS inhibition activity were isolated from seaweeds that are well known to produce various quorum sensing inhibitors (QSIs), namely bromoperoxidase from a brown alga Laminaria digitate and floridoside, bentonicine, and isoethionic acid from a Korean red alga Ahnfeltiopsis flabelliformis [37,38].
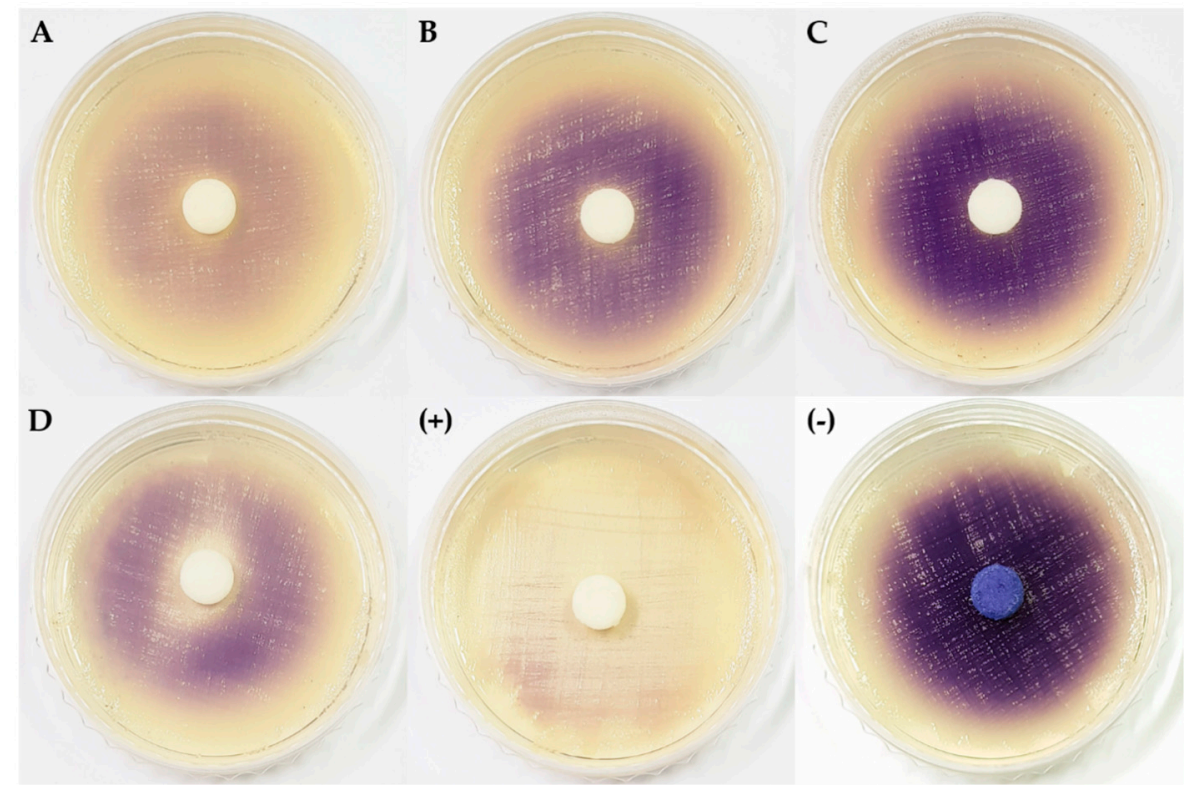

$(-)$

Figure 2. Quorum sensing inhibitory activity of extracts from four marine algicolous Arthrinium strains.

(A) Arthrinium sp. 1 KUC21228; (B) Arthrinium sp. 1 KUC21232; (C) Arthrinium sp. 5 KUC21289;

(D) Arthrinium sp. 6 KUC21321; (+) positive control (piericidin A); (-) negative control (DMSO).

In fact, many filamentous fungi associated with the plant rhizosphere have been reported to degrade 3-oxo-C6-HSL enzymatically [39]. Therefore, it was suggested that these seaweed-endophytic Arthrinium species can produce QSIs that are expected to be lactonase or other kinds of AHL-degrading enzymes, which degrade 3-oxo-C6-HSL and assist in resistance to bacterial biofilms in seaweeds. Otherwise, it could be norlichexanthone, a known metabolite of Arthrinium sp., reported to inhibit the QS mechanism in Staphylococcus aureus, a human pathogen [40]. Considering that arthpyrones F-I and apiosporamide were reported as antibacterial compounds from marine Arthrinium sp., some marine Arthrinium species may directly inhibit seaweed-pathogenic bacteria [16]. The three new seaweed-endophytic Arthrinium strains were revealed to be potential QSI producers, which makes them valuable as a source of biological compounds that inhibit the bacterial biofilm, which causes huge economic losses in many areas, such as food, aquaculture, wastewater treatment, and the shipping 
industry [41,42]. The selected fungi will be subjected to an in vitro experiment as a subsequent screening by quantifying their activity.

\subsection{Antioxidant Compound from Arthrinium sp. 10}

The extract of Arthrinium sp. 10 KUC21332, a new species candidate with the highest radical-scavenging activity, was selected to identify the active compound. A bioassay-guided isolation of this extract afforded gentisyl alcohol (1) (Figure 3). The chemical structure was identified using spectroscopic data and a comparison with literature data [43]. The ${ }^{1} \mathrm{H}$ and ${ }^{13} \mathrm{C}$ NMR spectra, LC chromatogram, UV spectrum, and MS spectra of Compound $\mathbf{1}$ are shown in the Supplementary Materials (Figures S1-S4). In addition, the results of comparative analysis of A. saccharicola KUC21221 extract, Arthrinium sp. 10 KUC21332 extract, and gentisyl alcohol using ultra-performance liquid chromatography (UPLC) with a photodiode array (PDA) detector confirmed that the antioxidant compound of A. saccharicola KUC21221 is the same as that of Arthrinium sp. 10 KUC21332, that is gentisyl alcohol (Figure S5).<smiles>OCc1cc(O)ccc1O</smiles>

Figure 3. Structure of Compound 1.

The radical-scavenging activity of Compound 1 was evaluated using the ABTS and DPPH assays. As described in Table 2, it exhibited higher activities than the positive control (ascorbic acid), which corresponds to the result of a previous report [44]. Gentisyl alcohol has also been reported to have proangiogenic, caspase inhibition, histone deacetylases inhibition, antibacterial (against methicillin-resistant Staphylococcus aureus), antifungal (against Colletotrichum gloeosporioides), antileishmanial (against Leishmania donovani), and cytotoxic (against human breast and colon cancer cell lines, MCF-7 and HT-29, respectively, and against sea urchin Strongylocentrotus intermedius) activity [45-53]. This is the first report of the production of gentisyl alcohol from the genus Arthrinium.

Table 2. ABTS and DPPH radical-scavenging activity of Compound $\mathbf{1}$ isolated from Arthrinium sp. 10 KUC21332.

\begin{tabular}{|c|c|c|}
\hline \multirow{2}{*}{ Compound } & \multicolumn{2}{|c|}{ Antioxidant Activity $\left(\mathrm{IC}_{50}, \mu \mathrm{M}\right)$} \\
\hline & ABTS $^{a}$ & DPPH $^{b}$ \\
\hline Gentisyl alcohol (1) & 26.43 & 28.74 \\
\hline Ascorbic acid * & 77.79 & 38.61 \\
\hline
\end{tabular}

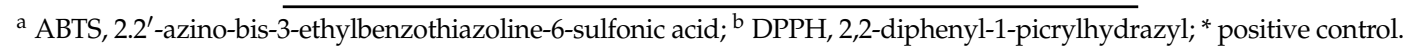

\section{Materials and Methods}

\subsection{Microorganisms}

\subsubsection{Fungal Resources}

Marine-derived Arthrinium spp. used in this study were obtained from the Korea University Culture (KUC) collection and Marine Fungal Resource Bank (MFRB) at Seoul National University as a marine bioresource bank of Korea by the Ministry of Oceans and Fisheries. Asteromyces cruciatus SFC20161110-M19 was obtained from MFRB to use as a target fungus of the antifungal assay.

The algicolous fungi were isolated according to the following procedure [1,19]. Marine algae and the egg masses of A. japonicus were washed with sterile $3.44 \%$ artificial sea water (ASW) and cut 
into $5-\mathrm{mm}^{2}$ squares. The pieces were placed on each of three culture plates: dichloran rose bengal chloramphenicol agar (Difco, Sparks, MD, USA), glucose yeast extract agar $(1 \mathrm{~g} / \mathrm{L}$ glucose, $0.1 \mathrm{~g} / \mathrm{L}$ yeast extract, $0.5 \mathrm{~g} / \mathrm{L}$ peptone, and $15 \mathrm{~g} / \mathrm{L}$ agar), and Sabouraud dextrose agar (Difco, Sparks, MD, USA) supplemented with $3.44 \%$ ASW, $0.01 \%$ streptomycin, and $0.01 \%$ ampicillin to prevent bacterial growth. The plates were incubated at $25^{\circ} \mathrm{C}$ for $7-15$ days, and the grown fungi were transferred to a potato dextrose agar (PDA, Difco, Sparks, MD, USA) plate with $3.44 \%$ ASW periodically.

\subsubsection{DNA Extraction, PCR, and Identification}

Genomic DNA extraction was performed using fungal culture grown on malt extract agar by the AccuPrep Genomic DNA Extraction kit (Bioneer, Seoul, Korea). The DNA sequences of KUC21221, KUC21229, KUC21261, KUC21228, KUC21232, and KUC21220 were obtained from our previous research [1]. PCR reactions were performed with three different primer regions using the AccuPower PCR Premix Kit (Bioneer, Seoul, Korea). ITS (forward: ITS1F (5'-CTTGGTCATTTAGAGGAAGTAA- $3^{\prime}$ ) and reverse: LR3 (5'-CCGTGTTTCAAGACGGG-3') [54,55], LSU (forward: LR0R $\left(5^{\prime}\right.$-ACCCGCTGAACTTAAGC-3') and reverse: LR5 (5'-TCCTGAGGGAAACTTCG-3') or LR7 (5'-TACTACCACCAAGATCT-3') [56], TUB (forward: T10 (5'-CATCGAGAAGTTCGAGAAGG-3') or Bt2a (5'-GGTAACCAAATCGGTGCTGCTTTC-3') and reverse: T2 (5'-TAGTGACCCTTGGCCCA GTTG-3') or Bt2b (5'-ACCCTCAGTGTAGTGACCCTTGGC-3')) [57,58], and EF-1 $\alpha$ (forward: EF1-728F (5'-GGA(G/A)GTACCAGT(G/C)ATCATGTT-3') and reverse: EF2 (5'-GGA(G/A)GTACCAGT(G/C) ATCATGTT-3') $[59,60]$ were amplified under the temperature cycling parameters as follows. For ITS and LSU, $95{ }^{\circ} \mathrm{C}$ for $4 \mathrm{~min}$, followed by 30 cycles of $95^{\circ} \mathrm{C}$ for $30 \mathrm{~s}, 55^{\circ} \mathrm{C}$ for $30 \mathrm{~s}$, and $72{ }^{\circ} \mathrm{C}$ for $30 \mathrm{~s}$; an elongation step of $72{ }^{\circ} \mathrm{C}$ for $5 \mathrm{~min}$ was performed at the end. For TUB, $95^{\circ} \mathrm{C}$ for $5 \mathrm{~min}$, followed by 30 cycles of $95^{\circ} \mathrm{C}$ for $35 \mathrm{~s}, 55$ or $56^{\circ} \mathrm{C}$ for $50 \mathrm{~s}$, and $72{ }^{\circ} \mathrm{C}$ for $2 \mathrm{~min}$; an elongation step was performed at $72{ }^{\circ} \mathrm{C}$ for $7 \mathrm{~min}$. For EF- $1 \alpha, 94^{\circ} \mathrm{C}$ for $2 \mathrm{~min}$, followed by 29 cycles of $93^{\circ} \mathrm{C}$ for $30 \mathrm{~s}, 55$ or $56^{\circ} \mathrm{C}$ for $30 \mathrm{~s}$, and $72{ }^{\circ} \mathrm{C}$ for 1 minute; an elongation step was performed at $72{ }^{\circ} \mathrm{C}$ for $10 \mathrm{~min}$. DNA sequencing was executed by Macrogen (Seoul, Korea) using the Sanger method with a 3730xl DNA Analyzer (Life technology, Carlsbad, CA, USA). The obtained DNA sequences were submitted to the GenBank, and the accession numbers are presented in Table 1.

\subsubsection{Phylogenetic Analysis}

The obtained DNA sequences with reference sequences (Table S1) obtained from GenBank using a BLAST search were proofread, aligned using MAFFT 7.397, and modified manually using MacClade v4.08 (http:/ / macclade.org) [61,62]. They were tested by MrModeltest v2.3 (https:/ / www.softpedia. $\mathrm{com} /$ get/Science-CAD/MrModeltest.shtml) with default options using the AIC [63]. Bayesian analysis was performed by MrBayes v3.2.1 (http:/ / nbisweden.github.io/MrBayes) [64]. Two operations were performed and contained 1,000,000 generations. For each operation, the result of every 100th generation was sampled. Among them, the first $25 \%$ of the trees was removed, and the last $75 \%$ was selected. A phylogenetic tree was constructed according to the 50\% majority-rule, and tree reliability was confirmed by the posterior probability.

\subsection{Preparation of Fungal Extracts}

All of the fungal species were precultured on 20-mL Petri dishes containing PDA at $25^{\circ} \mathrm{C}$ until mycelia covered the dishes. After the preculture period, three agar plugs with mycelia were transferred to Petri dishes $(150 \times 20 \mathrm{~mm})$ containing $50 \mathrm{~mL}$ of PDA and incubated at $25^{\circ} \mathrm{C}$ for seven days in darkness. The fungal cultures were incubated in triplicate. To obtain fungal extracts, the solid media with mycelia were extracted with $200 \mathrm{~mL}$ of methanol for $24 \mathrm{~h}$, followed by filtration with Whatman No.1 filter paper. Filtrates were dried at $37{ }^{\circ} \mathrm{C}$ under a vacuum and cooled at $4{ }^{\circ} \mathrm{C}$ during circulation. The dried residues were redissolved in a half and half percentage of water-ethyl acetate solution. After six hours, the portion of ethyl acetate was collected and evaporated under the same temperature condition mentioned above. The dried extracts were maintained in the $20-\mathrm{mL}$ scintillation vials at $4{ }^{\circ} \mathrm{C}$ 
until use. To obtain a large amount of crude extracts for separating the bioactive compound, a culture and extraction were carried out using the same method in 200 Petri dishes.

\subsection{Biological Assays}

\subsubsection{Antioxidant Assay}

ABTS Radical-Scavenging Assay

ABTS (Sigma-Aldrich, Inc., St. Louis, MO, USA) was dissolved in phosphate-buffered saline (PBS, $\mathrm{pH}$ 7.4) to $7 \mathrm{mM}$. Then, the ABTS solution was mixed with potassium persulfate solution that was dissolved in PBS to $2.45 \mathrm{mM}$. The mixture was stored in the dark at room temperature for $24 \mathrm{~h}$. After the $\mathrm{ABTS}^{\bullet+}$ radical was formed, the ABTS solution was diluted with PBS to an absorbance of 0.70 $( \pm 0.02)$ at a wavelength of $734 \mathrm{~nm}$. Then, $990 \mu \mathrm{L}$ of ABTS radical solution and $10 \mu \mathrm{L}$ of fungal extract $(10 \mathrm{mg} / \mathrm{mL}$ in DMSO) were reacted in a cuvette. The absorbance was measured at $734 \mathrm{~nm}$ after $6 \mathrm{~min}$ using a spectrophotometer (Sunrise ${ }^{\mathrm{TM}}$, Tecan, Männedorf, Switzerland).

\section{DPPH Radical-Scavenging Assay}

DPPH (Sigma-Aldrich Inc., St. Louis, MO, USA) was dissolved in $80 \%$ methanol at $150 \mu \mathrm{M}$. The $200 \mu \mathrm{L}$ of DPPH solution and $22 \mu \mathrm{L}$ of the fungal extracts $(10 \mathrm{mg} / \mathrm{mL})$ was mixed in each well in a 96-well plate. The plate was allowed to reach a steady state for $30 \mathrm{~min}$ at room temperature. The absorbance was measured at $540 \mathrm{~nm}$.

\subsubsection{Antifungal Assay}

Antifungal activity was determined in a 96-well plate using the microtiter broth dilution method [65]. Twenty-five microliters of spore suspensions $\left(4 \times 10^{5}\right.$ conidia/mL $)$ of Asteromyces cruciatus SFC20161110-M19 were added to each well containing $25 \mu \mathrm{L}$ of $4 \times$ potato dextrose broth and $49 \mu \mathrm{L}$ of D.W. Finally, the fungal extracts were added to a final concentration of $100 \mu \mathrm{g} / \mathrm{mL}$. The inoculated 96-well plates were incubated at $25^{\circ} \mathrm{C}$, for three days. To determine the minimum inhibitory concentration (MIC), the extracts with lower concentrations $(50,25,12.5,6.5 \mu \mathrm{g} / \mathrm{mL}$ ) were tested.

\subsubsection{Tyrosinase Inhibition Assay}

A tyrosinase inhibition assay was conducted based on the method described by Lai et al. (2009) [66]. Forty microliters of fungal extract $(2.5 \mathrm{mg} / \mathrm{mL}$ in $50 \%$ DMSO), $70 \mu \mathrm{L}$ of $0.1 \mathrm{M}$ potassium phosphate buffer ( $\mathrm{pH} 6.8$ ), and $30 \mu \mathrm{L}$ of tyrosinase from mushroom $(0.02 \mathrm{mg} / \mathrm{mL}$ in the buffer; Sigma Aldrich, St. Louis, MO, USA) were mixed in a 96-well plate. The mixture was heated to $30{ }^{\circ} \mathrm{C}$ for five minute, and $100 \mu \mathrm{L}$ of $2.5 \mathrm{mM}$ L-DOPA (Sigma Aldrich, St. Louis, MO, USA) was added to the well. After $30 \mathrm{~min}$, the reaction was terminated by putting the plate in ice, and the absorbance was measured at $492 \mathrm{~nm}$. Kojic acid (Sigma Aldrich, St. Louis, MO, USA) was used as a positive control, and a mixture without L-DOPA was regarded as a blank.

\subsubsection{Quorum Sensing Inhibition Assay}

QSI screening was performed based on the inhibition of violacein production by Chromobacterium violaceum CV026 strains under culture conditions supplemented with an exogenous QS molecule, 3-oxo-C6-HSL [67]. The C. violaceum CV026 cultured overnight was diluted with LB medium (5 g of yeast extract, $10 \mathrm{~g}$ of tryptone, and $5 \mathrm{~g}$ of $\mathrm{NaCl}$ in a liter of D.W.) to an $\mathrm{OD}_{600 \mathrm{~nm}}$ of 0.1 , and $97 \mu \mathrm{L}$ of the diluted culture were added to each well of a 96-well plate. One microliter of 3-oxo-C6-HSL (final concentration of $10 \mu \mathrm{M}$; Sigma-Aldrich, St. Louis, MO, USA) and two microliters of fungal extract (diluted to $10 \mathrm{mg} / \mathrm{mL}$ in DMSO) was added to each well. As a negative control and positive control, DMSO and $100 \mathrm{nM} \mathrm{(Z)-4-bromo-5-(bromomethylene)-2(5H)-furanone} \mathrm{(Furanone} \mathrm{C-30;} \mathrm{Sigma-Aldrich,}$ 
St. Louis, MO, USA) were used, respectively. After $16 \mathrm{~h}$ at $28^{\circ} \mathrm{C}, 100 \mu \mathrm{L}$ of DMSO was added to each well and vigorously shaken for an hour at room temperature to determine the production of violacein.

The selected extracts were further examined using a paper disc method. Fifteen microliters of the diluted culture of $C$. violaceum CV026 was spread on an LB agar plate, and a paper disc (diameter $8 \mathrm{~mm}$; Advantec, Tokyo, Japan) impregnated with $40 \mu \mathrm{L}$ of extract and $1 \mu \mathrm{L}$ of $1 \mathrm{mM}$ 3-oxo-C6-HSL was placed in the center of the plate. DMSO was used as a negative control, and piericidin A isolated from Streptomyces xanthocidicus KPP01532 was used as a positive control [67]. The plates were incubated overnight at $28^{\circ} \mathrm{C}$.

\subsection{Isolation and Identification of the Bioactive Compound}

\subsubsection{Experimental Procedures}

Column chromatography was performed by silica gel (200-300 mesh, Merck, Darmstadt, Germany), and prep-HPLC was performed by a Waters system consisting of a 515 pump and 2996 PDA detector (Milford, MA, USA). NMR spectra were recorded on a Varian 500-MHz NMR spectrometer (Palo Alto, CA, USA), and ESIMS spectra were recorded on an LCQ Fleet Ion Trap MS spectrometer (Thermo Scientific, Madison, WI, USA). UPLC was performed using Waters ACQUITY UPLC ${ }^{\mathrm{TM}}$.

\subsubsection{Bioassay-Guided Isolation}

The crude extract $(826.2 \mathrm{mg})$ was fractionated on a column $(3 \times 30 \mathrm{~cm})$ packed with a silica gel using elution with $n$-hexane-EtOAc gradient ratios (1:0 to 0:1) to provide seven fractions (F1-F7). Among the seven fractions, F5 exhibited $100 \%$ DPPH radical-scavenging activity at a concentration of $500 \mu \mathrm{g} / \mathrm{mL}$ and was separated into five peak fractions (F5-P1-F5-P5) by prep-HPLC (5-30\% ACN, $8 \mathrm{~mL} / \mathrm{min}$ ). The first subfraction (F5-P1) exhibited 100\% DPPH radical-scavenging activity at a concentration of $10 \mu \mathrm{g} / \mathrm{mL}$ and was further purified by silica gel column chromatography $(1 \times 20 \mathrm{~cm})$ using elution with $\mathrm{CHCl}_{3}-\mathrm{MeOH}$ in gradient ratios (50:1-20:1) to provide target Compound 1 (F5-P1-2, $61.9 \mathrm{mg})$.

Gentisyl alcohol (1) ${ }^{1} \mathrm{H}$ NMR (DMSO- $\left.d_{6}, 500 \mathrm{MHz}\right) \delta_{\mathrm{H}} 8.58(2 \mathrm{H}$, br s, overlap, OH-2 and OH-5), $6.75(1 \mathrm{H}, \mathrm{d}, J=3.0 \mathrm{~Hz}, \mathrm{H}-6), 6.55(1 \mathrm{H}, \mathrm{d}, J=8.5 \mathrm{~Hz}, \mathrm{H}-3), 6.43(1 \mathrm{H}, \mathrm{d}, J=8.5,3.1 \mathrm{~Hz}, \mathrm{H}-4), 4.92(1 \mathrm{H}, \mathrm{br}$ s, OH-7), 4.41 (2H, br s, H-7); ${ }^{13} \mathrm{C}$ NMR (DMSO- $\left.d_{6}, 125 \mathrm{MHz}\right) \delta_{\mathrm{C}} 150.2(\mathrm{C}-5), 146.8(\mathrm{C}-2), 129.8(\mathrm{C}-1)$, 115.5 (C-3), 114.4 (C-6), 113.7 (C-4), 58.7 (C-7); ESIMS $(m / z) 139.2[\mathrm{M}-\mathrm{H}]^{-}, 185.1[\mathrm{M}+\mathrm{COOH}]^{-}$.

\section{Conclusions}

The multi-gene phylogenetic analysis revealed that 28 Arthrinium strains isolated from various marine environments consisted of four known species and 11 new species candidates. Most of them exhibited strong antioxidant activity, and some showed antifungal, quorum sensing inhibition, and tyrosinase inhibition activity. It was demonstrated that marine algicolous Arthrinium spp. can support the regulation of reactive oxygen species in symbiotic algae and protect against pathogens and bacterial biofilm formation. They can form a symbiotic relationship in a way that increases the viability and environmental competitiveness of symbiotic algae in exchange for nutrients such as mannitol, which is the main photosynthetic product of brown algae [68]. A strong antioxidant compound was isolated from a new species, Arthrinium sp. 10 KUC21332, and identified to be gentisyl alcohol (1), and the antioxidant compound of $A$. saccharicola KUC21221 was identical. These results suggest that many Arthrinium spp. remain unexploited in the marine environment, and marine Arthrinium spp. are a great source of bioactive compounds. Other bioactive compounds from marine Arthrinium spp., including antifungal compounds, tyrosinase inhibitors, and QSIs, will be isolated and identified in the near future.

Supplementary Materials: The following are available online at http:/ /www.mdpi.com/1660-3397/16/12/508/ s1: Figure S1: ${ }^{1} \mathrm{H}$ NMR spectrum of Compound 1, Figure S2: ${ }^{13} \mathrm{C}$ NMR spectrum of Compound 1, Figure S3: LC chromatogram and UV spectrum of Compound 1, Figure S4: MS spectra of Compound 1, Figure S5: UPLC peaks 
and UV spectrum of A. saccharicola KUC21221 extract, Arthrinium sp. 10 KUC21332 extract, and Compound 1. The arrows indicate gentisyl alcohol, Table S1: GenBank accession numbers of the reference sequences used in the phylogenetic analysis in this study, Table S2: Marine algicolous Arthrinium spp. exhibiting antifungal and tyrosinase inhibition activity.

Author Contributions: Conceptualization, Y.M.H., J.-H.H., and J.-J.K.; methodology, M.Y.P., J.E.K., J.-H.H., and S.M.R.; validation, B.S.K., D.L. and J.-J.K.; formal analysis, Y.M.H. and M.Y.P.; investigation, Y.M.H., K.K., and S.L.K.; resources, Y.W.L., C.K., and J.-J.K.; writing, original preparation, Y.M.H., K.K., S.M.R., S.L.K., M.Y.P., and J.E.K.; writing, review and editing, B.S.K., D.L., and J.-J.K.; visualization, S.M.R. and S.L.K.; supervision, B.S.K., D.L., and J.-J.K. project administration, J.-J.K.; funding acquisition, J.-J.K.

Funding: This research was funded by National Research Foundation of Korea (NRF) funded by the Korean government (MSIT) grant number 2017R1A2B4002071. This research was also funded by the National Institute of Biological Resources (NIBR) under the Ministry of Environment, Republic of Korea, Grant Number 201701104.

Conflicts of Interest: The authors declare no conflict of interest.

\section{References}

1. Hong, J.-H.; Jang, S.; Heo, Y.M.; Min, M.; Lee, H.; Lee, Y.M.; Lee, H.; Kim," J.-J. Investigation of marine-derived fungal diversity and their exploitable biological activities. Mar. Drugs 2015, 13, 4137-4155. [CrossRef] [PubMed]

2. Ellis, M.B. Dematiaceous Hyphomycetes; Commonwealth Mycological Institute: Kew, UK, 1971.

3. Sharma, R.; Kulkarni, G.; Sonawane, M.S.; Shouche, Y.S. A new endophytic species of arthrinium (apiosporaceae) from Jatropha podagrica. Mycoscience 2014, 55, 118-123. [CrossRef]

4. Crous, P.W.; Groenewald, J.Z. A phylogenetic re-evaluation of arthrinium. IMA Fungus 2013, 4, $133-154$. [CrossRef] [PubMed]

5. Seifert, K.A.; Gams, W. The genera of hyphomycetes. Persoonia 2011, 27, 119-129. [CrossRef] [PubMed]

6. Ellis, M. More Dematiaceous Hypomycetes; CABI Publishing: Kew, UK, 1976; p. 507.

7. Wang, M.; Tan, X.-M.; Liu, F.; Cai, L. Eight new arthrinium species from china. MycoKeys 2018, 1-24. [CrossRef]

8. Blunt, J.W.; Copp, B.R.; Keyzers, R.A.; Munro, M.H.; Prinsep, M.R. Marine natural products. Nat. Prod. Rep. 2015, 32, 116-211. [CrossRef] [PubMed]

9. Bugni, T.S.; Ireland, C.M. Marine-derived fungi: A chemically and biologically diverse group of microorganisms. Nat. Prod. Rep. 2004, 21, 143-163. [CrossRef]

10. Molinski, T.F.; Dalisay, D.S.; Lievens, S.L.; Saludes, J.P. Drug development from marine natural products. Nat. Rev. Drug Discov. 2009, 8, 6969-6985. [CrossRef]

11. Mousa, W.K.; Raizada, M.N. The diversity of anti-microbial secondary metabolites produced by fungal endophytes: An interdisciplinary perspective. Front. Microbiol. 2013, 4, 65. [CrossRef]

12. Tsukada, M.; Fukai, M.; Miki, K.; Shiraishi, T.; Suzuki, T.; Nishio, K.; Sugita, T.; Ishino, M.; Kinoshita, K.; Takahashi, K.; et al. Chemical constituents of a marine fungus, Arthrinium sacchari. J. Nat. Prod. 2011, 74, 1645-1649. [CrossRef]

13. Ebada, S.S.; Schulz, B.; Wray, V.; Totzke, F.; Kubbutat, M.H.; Müller, W.E.; Hamacher, A.; Kassack, M.U.; Lin, W.; Proksch, P. Arthrinins a-d: Novel diterpenoids and further constituents from the sponge derived fungus arthrinium sp. Bioorg. Med. Chem. 2011, 19, 4644-4651. [CrossRef] [PubMed]

14. Elissawy, A.M.; Ebada, S.S.; Ashour, M.L.; Özkaya, F.C.; Ebrahim, W.; Singab, A.B.; Proksch, P. Spiroarthrinols $\mathrm{a}$ and $\mathrm{b}$, two novel meroterpenoids isolated from the sponge-derived fungus arthrinium sp. Phytochem. Lett. 2017, 20, 246-251. [CrossRef]

15. Wei, M.-Y.; Xu, R.-F.; Du, S.-Y.; Wang, C.-Y.; Xu, T.-Y.; Shao, C.-L. A new griseofulvin derivative from the marine-derived arthrinium sp. Fungus and its biological activity. Chem. Nat. Compd. 2016, 52, 1011-1014. [CrossRef]

16. Bao, J.; Zhai, H.; Zhu, K.; Yu, J.-H.; Zhang, Y.; Wang, Y.; Jiang, C.-S.; Zhang, X.; Zhang, Y.; Zhang, H. Bioactive pyridone alkaloids from a deep-sea-derived fungus arthrinium sp. Ujnmf0008. Mar. Drugs 2018, 16, 174. [CrossRef]

17. Bao, J.; He, F.; Yu, J.-H.; Zhai, H.; Cheng, Z.-Q.; Jiang, C.-S.; Zhang, Y.; Zhang, Y.; Zhang, X.; Chen, G. New chromones from a marine-derived fungus, arthrinium sp., and their biological activity. Molecules 2018, 23, 1982. [CrossRef] 
18. Wang, J.; Wang, Z.; Ju, Z.; Wan, J.; Liao, S.; Lin, X.; Zhang, T.; Zhou, X.; Chen, H.; Tu, Z. Cytotoxic cytochalasins from marine-derived fungus Arthrinium arundinis. Planta Med. 2015, 81, 160-166. [CrossRef]

19. Park, M.S.; Oh, S.-Y.; Lee, S.; Eimes, J.A.; Lim, Y.W. Fungal diversity and enzyme activity associated with sailfin sandfish egg masses in korea. Fungal Ecol. 2018, 34, 1-9. [CrossRef]

20. Park, J.Y.; Cho, J.K.; Son, M.H.; Kim, K.M.; Han, K.H.; Park, J.M. Artificial spawning behavior and development of eggs, larvae and juveniles of the red spotted grouper, epinephelus akaara in korea. Dev. Reprod. 2016, 20, 31-40. [CrossRef]

21. Miao, L.; Kwong, T.F.N.; Qian, P.-Y. Effect of culture conditions on mycelial growth, antibacterial activity, and metabolite profiles of the marine-derived fungus arthrinium c.F. Saccharicola. Appl. Microbiol. Biotechnol. 2006, 72, 1063-1073. [CrossRef] [PubMed]

22. Huang, W.-Y.; Cai, Y.-Z.; Xing, J.; Corke, H.; Sun, M. A potential antioxidant resource: Endophytic fungi from medicinal plants. Econ. Bot. 2007, 61, 14-30. [CrossRef]

23. Wang, H.-M.D.; Chen, C.-C.; Huynh, P.; Chang, J.-S. Exploring the potential of using algae in cosmetics. Bioresour. Technol. 2015, 184, 355-362. [CrossRef] [PubMed]

24. Machu, L.; Misurcova, L.; Vavra Ambrozova, J.; Orsavova, J.; Mlcek, J.; Sochor, J.; Jurikova, T. Phenolic content and antioxidant capacity in algal food products. Molecules 2015, 20, 1118-1133. [CrossRef] [PubMed]

25. Smith, H.; Doyle, S.; Murphy, R. Filamentous fungi as a source of natural antioxidants. Food Chem. 2015, 185, 389-397. [CrossRef] [PubMed]

26. Bartasiute, A.; Westerink, B.H.; Verpoorte, E.; Niederländer, H.A. Improving the in vivo predictability of an on-line hplc stable free radical decoloration assay for antioxidant activity in methanol-buffer medium. Free Radic. Biol. Med. 2007, 42, 413-423. [CrossRef] [PubMed]

27. Skriptsova, A.V. Fucoidans of brown algae: Biosynthesis, localization, and physiological role in thallus. Russ. J. Mar. Biol. 2015, 41, 145-156. [CrossRef]

28. Raghukumar, S. Fungi in Coastal and Oceanic Marine Ecosystems; Springer: New York, NY, USA, 2017.

29. Gomaa, M.; Hifney, A.F.; Fawzy, M.A.; Issa, A.A.; Abdel-Gawad, K.M. Biodegradation of Palisada perforata (rhodophyceae) and sargassum sp.(phaeophyceae) biomass by crude enzyme preparations from algicolous fungi. J. Appl. Phycol. 2015, 27, 2395-2404. [CrossRef]

30. Yap, P.S.X.; Yiap, B.C.; Ping, H.C.; Lim, S.H.E. Essential oils, a new horizon in combating bacterial antibiotic resistance. Open Microbiol. J. 2014, 8, 6-14. [CrossRef]

31. Chang, T.-S. An updated review of tyrosinase inhibitors. Int. J. Mol. Sci. 2009, 10, 2440-2475. [CrossRef]

32. Kang, H.S.; Choi, J.H.; Cho, W.K.; Park, J.C.; Choi, J.S. A sphingolipid and tyrosinase inhibitors from the fruiting body of Phellinus linteus. Arch. Pharmacal. Res. 2004, 27, 742-750. [CrossRef]

33. Li, X.; Kim, M.K.; Lee, U.; Kim, S.-K.; Kang, J.S.; Choi, H.D.; Son, B.W. Myrothenones a and b, cyclopentenone derivatives with tyrosinase inhibitory activity from the marine-derived fungus myrothecium sp. Chem. Pharm. Bull. 2005, 53, 453-455. [CrossRef]

34. Chen, J.S.; Wei, C.I.; Marshall, M.R. Inhibition-mechanism of kojic acid on polyphenol oxidase. J. Agric. Food Chem. 1991, 39, 1897-1901. [CrossRef]

35. Olson, M.E.; Ceri, H.; Morck, D.W.; Buret, A.G.; Read, R.R. Biofilm bacteria: Formation and comparative susceptibility to antibiotics. Can. J. Vet. Res. 2002, 66, 86-92. [PubMed]

36. Rasmussen, T.B.; Skindersoe, M.E.; Bjarnsholt, T.; Phipps, R.K.; Christensen, K.B.; Jensen, P.O.; Andersen, J.B.; Koch, B.; Larsen, T.O.; Hentzer, M.; et al. Identity and effects of quorum-sensing inhibitors produced by Penicillium species. Microbiology 2005, 151, 1325-1340. [CrossRef] [PubMed]

37. Borchardt, S.A.; Allain, E.J.; Michels, J.J.; Stearns, G.W.; Kelly, R.F.; McCoy, W.F. Reaction of acylated homoserine lactone bacterial signaling molecules with oxidized halogen antimicrobials. Appl. Environ. Microbiol. 2001, 67, 3174-3179. [CrossRef] [PubMed]

38. Kim, J.S.; Kim, Y.H.; Seo, Y.W.; Park, S. Quorum sensing inhibitors from the red alga, Ahnfeltiopsis flabelliformis. Biotechnol. Bioprocess Eng. 2007, 12, 308-311. [CrossRef]

39. Kalia, V.C. Quorum sensing inhibitors: An overview. Biotechnol. Adv. 2013, 31, 224-245. [CrossRef] [PubMed]

40. Baldry, M.; Nielsen, A.; Bojer, M.S.; Zhao, Y.; Friberg, C.; Ifrah, D.; Heede, N.G.; Larsen, T.O.; Frøkiær, H.; Frees, D.; et al. Norlichexanthone reduces virulence gene expression and biofilm formation in Staphylococcus aureus. PLoS ONE 2016, 11, e0168305. [CrossRef]

41. Skandamis, P.N.; Nychas, G.-J.E. Quorum sensing in the context of food microbiology. Appl. Environ. Microbiol. 2012, 78, 5473-5482. [CrossRef] 
42. Schultz, M.P.; Bendick, J.A.; Holm, E.R.; Hertel, W.M. Economic impact of biofouling on a naval surface ship. Biofouling 2011, 27, 87-98. [CrossRef]

43. Chen, L.; Fang, Y.; Zhu, T.; Gu, Q.; Zhu, W. Gentisyl alcohol derivatives from the marine-derived fungus Penicillium terrestre. J. Nat. Prod. 2008, 71, 66-70. [CrossRef]

44. Nenkep, V.N.; Yun, K.; Li, Y.; Choi, H.D.; Kang, J.S.; Son, B.W. New production of haloquinones, bromochlorogentisylquinones a and $\mathrm{b}$, by a halide salt from a marine isolate of the fungus phoma herbarum. J. Antibiot. 2010, 63, 199-201. [CrossRef] [PubMed]

45. Kim, H.J.; Kim, J.H.; Lee, C.H.; Kwon, H.J. Gentisyl alcohol, an antioxidant from microbial metabolite, induces angiogenesis in vitro. J. Microbiol. Biotechnol. 2006, 16, 475-479.

46. Kim, J.; Kim, D.; Kim, M.; Kwon, H.; Oh, T.; Lee, C. Gentisyl alcohol inhibits apoptosis by suppressing caspase activity induced by etoposide. J. Microbiol. Biotechnol. 2005, 15, 532-536.

47. Lernoux, M.; Schnekenburger, M.; Dicato, M.; Diederich, M. Anti-cancer effects of naturally derived compounds targeting histone deacetylase 6-related pathways. Pharmacol. Res. 2018, 129, 337-356. [CrossRef] [PubMed]

48. Zwick, V.; Allard, P.M.; Ory, L.; Simões-Pires, C.A.; Marcourt, L.; Gindro, K.; Wolfender, J.L.; Cuendet, M. Uhplc-ms-based hdac assay applied to bio-guided microfractionation of fungal extracts. Phytochem. Anal. 2017, 28, 93-100. [CrossRef]

49. Li, Y.; Li, X.; Son, B.-W. Antibacterial and radical scavenging epoxycyclohexenones and aromatic polyols from a marine isolate of the fungus aspergillus. Nat. Prod. Sci. 2005, 11, 136-138.

50. Gupta, S.; Kaul, S.; Singh, B.; Vishwakarma, R.A.; Dhar, M.K. Production of gentisyl alcohol from Phoma herbarum endophytic in Curcuma longa L. And its antagonistic activity towards leaf spot pathogen Colletotrichum gloeosporioides. Appl. Biochem. Biotechnol. 2016, 180, 1093-1109. [CrossRef] [PubMed]

51. Malak, L.G.; Ibrahim, M.A.; Bishay, D.W.; Abdel-baky, A.M.; Moharram, A.M.; Tekwani, B.; Cutler, S.J.; Ross, S.A. Antileishmanial metabolites from Geosmithia langdonii. J. Nat. Prod. 2014, 77, 1987-1991. [CrossRef]

52. Ali, T.; Inagaki, M.; Chai, H.-B.; Wieboldt, T.; Rapplye, C.; Rakotondraibe, L.H. Halogenated compounds from directed fermentation of penicillium concentricum, an endophytic fungus of the liverwort Trichocolea tomentella. J. Nat. Prod. 2017, 80, 1397-1403. [CrossRef]

53. Smetanina, O.; Kalinovskii, A.; Khudyakov, Y.V.; Moiseenko, O.; Pivkin, M.; Menzorova, N.; Sibirtsev, Y.T.; Kuznetsova, T. Metabolites of the marine fungus Asperigillus varians kmm 4630. Chem. Nat. Compd. 2005, 41, 243-244. [CrossRef]

54. Gardes, M.; Bruns, T.D. Its primers with enhanced specificity for basidiomycetes-Application to the identification of mycorrhizae and rusts. Mol. Ecol. 1993, 2, 113-118. [CrossRef] [PubMed]

55. Bellemain, E.; Carlsen, T.; Brochmann, C.; Coissac, E.; Taberlet, P.; Kauserud, H. Its as an environmental DNA barcode for fungi: An in silico approach reveals potential pcr biases. BMC Microbiol 2010, 10, 189. [CrossRef] [PubMed]

56. Vilgalys, R.; Hester, M. Rapid genetic identification and mapping of enzymatically amplified ribosomal DNA from several cryptococcus species. J. Bacteriol. 1990, 172, 4238-4246. [CrossRef] [PubMed]

57. O'Donnell, K.; Cigelnik, E. Two divergent intragenomic rdna its2 types within a monophyletic lineage of the fungus fusarium are nonorthologous. Mol. Phylogenet. Evol. 1997, 7, 103-116. [CrossRef] [PubMed]

58. Glass, N.L.; Donaldson, G.C. Development of primer sets designed for use with the pcr to amplify conserved genes from filamentous ascomycetes. Appl. Environ. Microbiol. 1995, 61, 1323-1330. [PubMed]

59. O’Donnell, K.; Kistler, H.C.; Cigelnik, E.; Ploetz, R.C. Multiple evolutionary origins of the fungus causing panama disease of banana: Concordant evidence from nuclear and mitochondrial gene genealogies. Proc. Natl. Acad. Sci. USA 1998, 95, 2044-2049. [CrossRef] [PubMed]

60. Carbone, I.; Kohn, L.M. A method for designing primer sets for speciation studies in filamentous ascomycetes. Mycologia 1999, 91, 553-556. [CrossRef]

61. Maddison, D.R.; Maddison, W.P. Macclade 4: Analysis of Phylogeny and Character Evolution. Version 4.08 ; Sinauer Associates: Sunderland, MA, USA, 2005.

62. Katoh, K.; Standley, D.M. Mafft multiple sequence alignment software version 7: Improvements in performance and usability. Mol. Biol. Evol. 2013, 30, 772-780. [CrossRef]

63. Nylander, J.A.A. Mrmodeltest v2. Program Distributed by the Author; Evolutionary Biology Centre: Uppsala, Sweden, 2004. 
64. Ronquist, F.; Huelsenbeck, J.P. Mrbayes 3: Bayesian phylogenetic inference under mixed models. Bioinformatics 2003, 19, 1572-1574. [CrossRef]

65. Kim, J.D.; Han, J.W.; Hwang, I.C.; Lee, D.; Kim, B.S. Identification and biocontrol efficacy of Streptomyces miharaensis producing filipin iii against Fusarium wilt. J. Basic Microbiol. 2012, 52, 150-159. [CrossRef]

66. Lai, H.Y.; Lim, Y.Y.; Tan, S.P. Antioxidative, tyrosinase inhibiting and antibacterial activities of leaf extracts from medicinal ferns. Biosci. Biotechnol. Biochem. 2009, 73, 1362-1366. [CrossRef] [PubMed]

67. Kang, J.E.; Han, J.W.; Jeon, B.J.; Kim, B.S. Efficacies of quorum sensing inhibitors, piericidin a and glucopiericidin a, produced by Streptomyces xanthocidicus kpp01532 for the control of potato soft rot caused by Erwinia carotovora subsp. atroseptica. Microbiol. Res. 2016, 184, 32-41. [CrossRef] [PubMed]

68. Yamaguchi, T.; Ikawa, T.; Nisizawa, K. Pathway of mannitol formation during photosynthesis in brown algae. PCPhy 1969, 10, 425-440.

(C) 2018 by the authors. Licensee MDPI, Basel, Switzerland. This article is an open access article distributed under the terms and conditions of the Creative Commons Attribution (CC BY) license (http://creativecommons.org/licenses/by/4.0/). 